\title{
The Aspects of Psychosocial Risks Prevention in a Developing Country: Turkey
}

\author{
Ceyda Sahan ${ }^{1,2}$, Yucel Demiral $^{3}$ \\ 'Dokuz Eylul University, Occupational Medicine Department, Izmir, Turkey \\ ${ }^{2}$ Dokuz Eylul University, Graduate School of Health Sciences, Izmir, Turkey \\ ${ }^{3}$ Dokuz Eylul University, Public Health Department, Izmir, Turkey \\ Address for Correspondence: Ceyda Sahan, E-mail: ceyda_sahan@hotmail.com \\ Received: 08.02.2018; Accepted: 11.02.2018; Available Online Date: 23.01.2019 \\ (C) Copyright 2018 by Dokuz Eylül University, Institute of Health Sciences - Available online at www.jbachs.org \\ Cite this article as: Sahan C, Demiral Y. The Aspects of Psychosocial Risks Prevention in a Developing Country: Turkey. J Basic Clin Health Sci 2019; 3:30-34. https://doi.org/10.30621/ \\ jbachs.2019.511
}

*This study's results were presented as Country Case Report of Turkey on E-IMPRO project's website.

\begin{abstract}
Purpose: The aims of the study were determining the main psychosocial risks and identifying the role of workers' representatives/unions, managers, and occupational health and safety (OHS) professionals to improve workers' participation in the psychosocial risk prevention.

Methods: This is a qualitative research. Three volunteering companies, those agreed to participate, were selected in Turkey. Interviews were conducted with workers' /union reps and managers in each company, separately. The data were collected through semi-structured focus group interviews between 14th April-2nd May 2014. A total of 13 managers and 19 workers were interviewed in 3 workplaces. Interviews were carried out with tape-recording accompanied by note-taking. The content analysis method was evaluated by two researchers.

Results: There is no policy or legislation about psychosocial risk evaluation and prevention in Turkey. Employers and employees were not aware of psychosocial risks. Job insecurity, high workload, low job control and the identification of economic problems are the priority problems to be assessed in this process. While the main barriers for the participative psychosocial risk prevention process were lack of laws and regulations, communication gaps, financial requirements, pressure associated with production and quotas, excessive monitoring of workers' performance; the main drivers were management's supportive approach, justice, role clarity, and rewards.

Conclusion: Psychosocial risks must be assessed in all workplaces to change working conditions and the legal regulations should be done clearly on psychosocial risk prevention. The cooperation should be achieved with the union and workers' representatives, and their support and experiences should be utilized.
\end{abstract}

Keywords: psychosocial, risk assessment, work, prevention, drivers, barriers

\section{INTRODUCTION}

During the last couple of decades, there have been profound changes in working life, including increasing variability of working times and decreasing the membership of unionization, raise in sub-contracted working and precarious employment cause newly emerging risk factors that adversely affect occupational health and safety (OHS) in the workplaces $(1,2)$. Especially in developed and developing countries; the scope of work, the relationship between organization and management, the employees' abilities and requirements changed due to improving of service sector and information technology. Particularly, psychosocial risks in the workplace has become important with increased work load, decreased job control by means of monitoring of the performance and raising fix term contractual and job insecurity (3-5). Many psychosocial risk factors have been identified such as complexity, meaning, and variability of work, mental workload, time pressure, variable working times, career perspective, role conflict, education, personal relationships, social support, work-home conflict, age and cultural discrimination (1). While employees' knowledge and skills are not sufficient to answer the job demands and pressure, work stress occurs. Poor work organization, poor management, and dissatisfaction with working conditions may cause work stress by increasing extreme and uncontrollable demands and pressures (6). Employees influenced by work stress may be depressed and anxious. These conditions may lead to physical problems such as heart disease, digestive problems, increased blood pressure, headache or musculoskeletal diseases (6). Work stress may also cause that increased absenteeism, loss of interest in work, reduction in performance and productivity of employees and increase in work accidents (6). In many countries, there are lots of laws and regulations for occupational health and safety. According to them, psychosocial risk assessment should be carried out to record the changes of the working conditions. It 
is reported that European countries and Canada have advanced surveillance systems which were established for monitoring psychosocial risks in the workplace.

Some countries such as Australia attempts to progress in this area, but in many parts of the world there is not any effort in this regard (7). European Union (EU) Framework Directive 89/391 is enacted to improve occupational health and safety in EU Countries, includes psychosocial risk prevention. But the psychosocial risks have low priority for some of the EU countries (8). The absence of awareness on this issue, the complexity of psychosocial risk factors and difficulties of coping with them are the main reasons of this condition (9).

The main priorities in the field of occupational health and safety in developed countries are stress, aging workforce, right to know, informed consent, transparency, new chemicals, ergonomics, manual handling, allergy, indoor air, new technologies, occupational health services, management and safety culture. Besides, the actual priorities in developing countries are injury/accident prevention, monitoring and surveillance of psychosocial risks, work-related stress, violence, harassment at work, substance abuse and risky behaviours, capacity building, infectious diseases, musculo-skeletal disorders, chemicals, noise, and biological agents, safety culture, health and safety standards, legislation on OHS, registration, surveillance and data collection on workers' health (10).

Turkey's strategic position and due to the fact that it is a developing country occupational health issue in the country is under the influence of numerous political and financial factors in the international area. There has been a rapid reduction in employment in the agricultural sector particularly after 1990'. By the year $2017,21 \%$ of the working population is employed in the agricultural sector while $19 \%$ in industry, $53 \%$ in services, and $8 \%$ in construction (11). Unemployment rate is very high $(10.7 \%$ in 2017) (11). Turkey is progressively becoming a country wherein cheap labour force is employed in informal sector that is labourintensive and insecure (12). The Occupational Health and Safety Act (No. 6331) has been enacted in 2012 as a reflection of the EU harmonization process. According to these regulations on $\mathrm{OHS}$, risk assessment in the workplace is a legal requirement. Psychosocial risks are not mentioned in these regulations (13).

The aims of the study were determining the main psychosocial risks, identifying the role of managers, workers' reps/unions, OHS professionals and key elements to improve OHS workers' reps participation in the psychosocial risk prevention.

\section{METHODS}

This is a qualitative research and three volunteering companies, that agreed to participate, were selected in Turkey. Six interviews were conducted with workers' /union reps and managers in each company, separately. A total of 13 managers and 19 workers were interviewed in 3 workplaces (Table 1). The average interview time was 38 (26-42) minutes. The data were collected through semistructured focus group interviews between 14 $4^{\text {th }}$ April-2 ${ }^{\text {nd }}$ May 2014.
Participants were interviewed using a semi-structured interview guide. The main psychosocial risk situations were discussed by the interview questions. A short education on psychosocial risks has been carried out prior to each interview. Verbal consent was obtained from all participants.

Since the study is the part of international Project entitled E-IMPRO (European Union project Reference: VP/2013/001; VS/2013/0395) Improving methods of psychosocial risks anticipation in Europe, individual Ethical approval was not obtained.

The main questions were, "What are the main psychosocial risk factors in the workplace?", "Is there any psychosocial risk prevention intervention?", "What are the roles of managers, workers and OHS professionals in psychosocial risk prevention?", "What are drivers and barriers in the participative psychosocial risk prevention?" and "What do you recommend for the participative psychosocial risk assessment process to change working conditions?".

The interviews were recorded, transcribed and evaluated using content analysis. Content analysis was conducted manually. For statistical analyses, Excel 2007 (Microsoft Inc.; Redmond, Washington, United States of America) was used. The texts were encoded separately by two researchers and then a common list of codes was created to identify the themes. The main themes were psychosocial risk assessment policy, psychosocial risk factors in the workplace, the roles of managers, workers, OHS professionals and union, key elements in the participative psychosocial risk prevention.

\section{RESULTS}

There is no policy or legislation about psychosocial risk evaluation and prevention in Turkey. Employers and employees were not aware of this issue clearly. Surprisingly, psychosocial risks were misunderstood by many of the OHS professionals. They perceived that psychosocial risks were only related with individual characteristics of the workers or psychological status rather than the organizational problems. Therefore, organizational psychosocial risk assessment was not performed in the participated workplaces.

According to both managers and workers' reps, the most significant risk factor was heavy workload. The workers sometimes work under pressure to meet a deadline already specified for customers. Job controls were missing owing to pressures associated with time and quotas in all workplaces. There were some problems associated with role clarity even though they attempted and managed to solve such problems to some extent. According to workers' reps, social relationships with each other were generally good, but their relationship with the managers was rather limited. All the managers expressed that performancebased system disrupted social relationships among the workers. Because they argued that dismissal was based on performance evaluation so that this situation led to competition among workers. The job insecurity declared as one of the vital problems 


\begin{tabular}{|c|c|c|c|}
\hline & CASE 1 & CASE 2 & CASE 3 \\
\hline Activity of workplace & $\begin{array}{l}\text { Manufacturing electric cables for the } \\
\text { automotive industry (NACE: 2931) }\end{array}$ & $\begin{array}{l}\text { Manufacturing household } \\
\text { appliance molds (NACE: 27.5.1) }\end{array}$ & Gold mining (NACE: 072901) \\
\hline Numbers of employees & 2200 & 157 & 431 \\
\hline OHS unit & Yes & Yes & Yes \\
\hline Authorized union & Yes & No & Yes \\
\hline Number of interviewed people & $\begin{array}{l}5 \text { managers, } \\
8 \text { workers' union representatives }\end{array}$ & $\begin{array}{l}4 \text { managers } \\
7 \text { workers' union representatives }\end{array}$ & $\begin{array}{l}4 \text { managers } \\
4 \text { workers' union representatives }\end{array}$ \\
\hline Changes in the last two years & $\begin{array}{l}\text { Increasing customer demands and } \\
\text { changeable workload }\end{array}$ & $\begin{array}{l}\text { Increased automatization and } \\
\text { planning enabled the same task to } \\
\text { be carried out with fewer workers. }\end{array}$ & $\begin{array}{l}\text { No considerable changes in terms of } \\
\text { investment, sales, and staff }\end{array}$ \\
\hline Prior OHS problems in the workplace & $\begin{array}{l}\text { Ergonomics, industrial accidents, and } \\
\text { night shifts, job insecurity }\end{array}$ & $\begin{array}{l}\text { Accidents, noise risk, usage of } \\
\text { personal protectors }\end{array}$ & None declared \\
\hline
\end{tabular}

in Case 1 (Table 1). The workers were anxious about getting dismissed on account of closure or downsizing. Also, the workers who worked in the other workplaces (Case 2 and 3) had few or no problems associated with job insecurity. They believed that they would have job security unless they committed a disgraceful offence or made a huge mistake. All managers reported that the workers who were responsible for the same tasks had almost the same social and economic conditions. They have scales regarding workload and wages. However, any differences in wages resulting from seniority were considered as equity by the workers. On the other hand, some of the workers reported that workload was not fairly distributed. Both the managers and workers indicated that economic problems, in particular, posed a significant psychosocial risk in the workplace. They stated having family problems due to economy and not being able to focus on what they were doing at work. None of the interviewers reported witnessing mobbing in the workplace or hearing about any such complaints.

The managers had significant roles to play in workload planning, overtime controls, and social support provision. They regarded themselves as effective in psychosocial risk prevention. Because the workers could only make suggestions, the managers were able to give the ultimate decision about psychosocial risk prevention. They became more sensitive to the prevention of all the risks involved in the workplace because of the sanctions imposed by the Occupational Health and Safety Act in Turkey.

The OHS professionals played key roles especially in ergonomics, industrial accidents, and equipment used for OHS; however, they believed that these professionals should also deal with psychosocial risk prevention. It was reported that lots of psychosocial risks had not been voiced in the OHS meetings yet, even though other risks were often discussed in such meetings. Some of the workers argued that the OHS professionals should not be paid by the employer on the ground that they could be on the employer's side simply because of the risk that they might lose their income. Furthermore, they expressed that some workers abstained from visiting the on-site doctor because of their anxiety that they could be among the first to get dismissed they happened to be regarded as sick. According to the managers, the OHS professionals were not viewed as representatives of the employer and they were present in the workplace on behalf of all the workers. They regarded the OHS professionals as part of the company playing a middle-of-the-road role on both the managers' and the workers' side.

The members of the union were not able to perceive risks owing to their insufficient knowledge and educational background. They were only effective in such subjects as holidays and wages, but they did not deal with other risks satisfactorily. Some of the workers believed that the union was take part on the employer's side. They said that the union should not safeguard mutual interests with the employer. And also, the union did not have a voice in the decision making processes and thus references to the union were not useful for the workers.

The main barriers for the participative psychosocial risk prevention process were lack of laws and regulations, communication gaps because of non-recognition due to populous workplace and shifts, workers' fear of the managers, operational blindness, disagreement with the employer owing to financial requirements for risk prevention, pressure associated with production and quotas, excessive monitoring of workers, the lack of a perspective on psychosocial risks owing to the abundance of certain industrial accidents and other risk factors.

The main drivers for the participative psychosocial risk prevention process were listed as follows: communication between the workers and management, management's supportive approach and cognizance of problems the workers might have, justice, role clarity, active participation to decision processes or using suggestion boards where anybody could freely express their problems, moral and material rewards for the workers.

\section{DISCUSSION}

In our study, awareness of psychosocial risks among managers and workers was not sufficient and risk assessment for psychosocial risks was not included in the OHS services. This could be explained by lack of specific policy and/or regulation for the prevention of psychosocial risks in Turkey. According to ESENER study, the most 
important step in the prevention of psychosocial risks was the existence of legal responsibilities and requirements (14). So workers need to be protected in relationship with the employer by legal regulations and supervision mechanisms (15). According to the ILO Employment Relationship Recommendation (No. 198); the working relationship between the employee and the employer must be determined by national legislation, regulations and collective agreements and the unequal bargaining position between the employee and the employer should be balanced (16). Work stress should be considered with issues at the macro level such as income inequality, social protection policy, unionization etc. (17).

It is known that increasing competition and flexibility in working life in recent years have made working conditions ruthless (15). According to our study; job insecurity, high workload, low job control and the identification of economic problems indicate that psychosocial risks are the priority problems to be assessed in this process.

In our study, we found that the main psychosocial risk factors in the workplaces reported during the interviews are workload, pressure of quota, working faster, over control, role ambiguity, performance-based systems, social relationships, job insecurity, inequality and economic conditions. According to ESENER study, poor communication between management and employees, poor co-operation amongst colleagues, lack of employee control in organizing their work, job insecurity, problems in supervisoremployee relationships, long or irregular working hours, an unclear human resources policy and discrimination were the main psychosocial risk factors in Turkey (18). Although there are concerns about work-related stress in Turkey, it is the worst country after Portugal on stress management procedures and standards (18).

E-IMPRO project aimed at identifying specific barriers and drivers in participative psychosocial risk prevention processes in Southern European countries (France, Italy and Spain) and Turkey (19). According to E-IMPRO, key issues in the participative processes were not so different when compared with ESENER (14). The main collective drivers of psychosocial risk prevention were the existence of legal regulations and consideration of requests from the employees or their representatives $(18,19)$. Also, a lack of awareness, a lack of resources and a lack of training were the main barriers of psychosocial risk prevention $(18,19)$. In addition, other barriers of this issue were found in our study as high unemployment, existence of informal employment, absence of independent unionized workers and workers' incredulity about working conditions changes. Many of the participants thought that the members of union were not able to perceive risks owing to their insufficient knowledge and educational background and they did not have a voice in the decision making processes. It is known that unions have an important role on ensuring workers' health, so their absence or weaknesses may lead to increase mortality and morbidity of the workers (20). The power and influence of trade unions are reduced due to difficulties in unionization in Turkey in recent years (21). Moreover, trade unions are not institutionally and legally protected against policies implemented by employers (21).

It is crucial to note that this study is the first about psychosocial risk prevention policy in Turkey. Also, qualitative research design allows for the subject to be understood through its detail, rather than analyzing causality in a specific domain. But it is known that qualitative studies cannot be generalized to the population. It is important to note that qualitative study features were strictly followed in this study e.g. face to face interviews with the employees and employers in a quiet place, using semi-structured questionnaires, recording and note taking by the researcher and independent data analysis performed by two researchers. The main limitation was not interviewing with occupational health and safety professionals. Notably, in our study, some workers have stated that occupational health and safety professionals are in favor of the employer. One of the most important reasons for this is the fact that OHS professionals are financed by employers. But, OHS professionals should pay attention to work ethics because of the need to be loyal to both the worker and the employer (22). It is also known that OHS professionals are exposed to intense pressure by insurance companies and employers (23). In this case, it can be said that the OHS professionals have different psychosocial risks due to their specific position.

Psychosocial risks must be assessed in all workplaces to change working conditions and the legal regulations should be done clearly on psychosocial risk prevention. Increasing the awareness about management and control of psychosocial risks in the workplaces by national level interventions is so important. The cooperation should be achieved with the union and workers' reps, and their support and experiences should be utilized. The autonomy of OHS professionals should be guaranteed to improve health and safety in the workplaces.

Acknowledgements: With the financial support of the European Commission, Employment, Social Affairs and Inclusion DG; Social Dialogue and Industrial Relations Call for proposals under SubProgram II: Improving expertise in the field of industrial relations (Reference: VP/2013/001; Budget heading 04.03.03.01; VS/2013/0395 E-IMPRO. Improving methods of psychosocial risks anticipation in Europe). Thank you to the workplaces for participation of this project. We also thank to all partners of E-IMPRO project partners for their support.

Informed Consent: Verbal consent was obtained from all participants.

Peer-review: Externally peer-reviewed.

Author Contributions: Concept - CŞ, YD; Design - CŞ, YD; Supervision - CŞ, YD; Materials - CŞ, YD; Data Collection and/or Processing - CŞ, YD; Analysis and/or Interpretation - CŞ, YD; Literature Search - CŞ, YD; Writing Manuscript - CŞ, YD; Critical Review - CŞ, YD

Conflict of Interest: No conflict of interest was declared by the authors. 


\section{REFERENCES}

1. Costa G. [Changes in work organization and management of psychosocial risk factors]. G Ital Med Lav Ergon 2008;30:106-109.

2. Clarke M, Lewchuk W, de Wolff A, King A. 'This just isn't sustainable': precarious employment, stress and workers' health. IJ Law Psychiatry 2007;30:311-326. [CrossRef]

3. Leka S, Kortum E. A European framework to address psychosocial hazards. J Occup Health 2008;50:294-296. [CrossRef]

4. Cox T, Griffiths A, Rial-González E, European Agency for Safety and Health at Work. Research on work-related stress. Luxembourg, Lanham, Md:: Office for Official Publications of the European Communities; Bernan Associates Distributor; 2000. 167 p.

5. Demiral $Y$, Ünal B, Kılıç B, et al. İş stresi ölçeğinin İzmir Konak Belediyesi'nde çalışan erkek işçilerde geçerlik ve güvenilirliğinin incelenmesi. Toplum Hekimliği Bülteni 2007;26:11-18.

6. Leka S, Griffiths A, Cox T. Work Organization and stress: systematic problem approaches for employers, managers and trade union representatives. Geneva: WHO; 2004

7. Dollard M, Skinner N, Tuckey MR, Bailey T. National surveillance of psychosocial risk factors in the workplace: An international overview. Work Stress 2007;21:1-29. [CrossRef]

8. Hämäläinen RM. The Europeanisation of occupational health services: a study of the impact of EU policies. Helsinki: Finnish Institute of Occupational Health; 2008.

9. Iavicoli S, Natali E, Deitinger P, et al. Occupational health and safety policy and psychosocial risks in Europe: the role of stakeholders' perceptions. Health Policy 2011;101:87-94. [CrossRef]

10. Kortum E, Leka S, Cox T. Psychosocial risks and work-related stress in developing countries: health impact, priorities, barriers and solutions. Int J Occup Med Environ Health 2010; 23(3):225-238. [CrossRef]

11. TURKSTAT. Labour Statistics 2017 Available from: [CrossRef]

12. Demiral $Y$, Sahan C. Drivers and Barriers for Participative Prevention Processes on Psychosocial Risks to Achieve Changes in Working Conditions Turkish Cases Report. ISTAS E-IMPRO; 2014. 26 p.
13. Gazete R. Iss Sağlığı ve Güvenliği Kanunu. 2012 Available from: [CrossRef]

14. Worker representation and consultation on health and safety: An analysis of the findings of the European Survey of Enterprises on New and Emerging. Luxembourg: European Agency for Safety and Health at Work (EU-OSHA); 2012.

15. Zeytinoğlu E. İş Hukukunda Esneklik ve 4857 Sayılı Kanunu'na Çeşitli Yansımaları. İstanbul Ticaret Üniversitesi Sosyal Bilimler Dergisi 2006;5:191-202.

16. ILO. Employment Relationship Recommendation, 2006 (No. 198) Available from: [CrossRef]

17. Dollard MF, Neser DY. Worker health is good for the economy: union density and psychosocial safety climate as determinants of country differences in worker health and productivity in 31 European countries. Soc Sci Med 2013;92:114-123. [CrossRef]

18. González E, Cockburn W, Irastorza X. ESENER - European Survey of Enterprises on New and Emerging Risks. Luxembourg: European Agency for Safety and Health at Work; 2010.

19. Llorens C, Moncada S. E-IMPRO Report: Drivers and Barriers for Participative Psychosocial Risk Prevention Processes to Change Working Conditions. E-IMPRO Project; 2014. 34 p.

20. Zoorob M. Does 'right to work' imperil the right to health? The effect of labour unions on workplace fatalities. Occup Environ Med 2018;75:736-738. [CrossRef]

21. Yıldırım E, Uçkan B. İşverenlerin Sendikasızlaştırma Modelleri ve Türkiye Örneği. Çalışma ve Toplum 2010;2:163-184.

22. Heikkinen $A M$, Wickström $G$, Leino-Kilpi $H$, Katajisto J. Privacy and dual loyalties in occupational health practice. Nurs Ethics 2007; 14:675-690. [CrossRef]

23. Higgins $P$, Orris P. Providing employer-arranged occupational medical care: conflicting interests. Occup Med 2002;17:601-606. 